\title{
Use of bone wax is related to increased postoperative sternal dehiscence
}

\author{
Cem Alhan ${ }^{1}$, Cem Arıtürk ${ }^{1}$, Sahin Senay ${ }^{1}$, Murat Okten $^{2}$, A. Umit Güllü ${ }^{1}$, Leyla Kilic ${ }^{3}$, Hasan Karabulut ${ }^{1}$, \\ Fevzi Toraman ${ }^{4}$ \\ ${ }^{1}$ Department of Cardiovascular Surgery, Acıbadem University School of Medicine, Istanbul, Turkey \\ ${ }^{2}$ Department of Cardiovascular Surgery, Acıbadem Kadikoy Hospital, Istanbul, Turkey \\ ${ }^{3}$ Department of Cardiovascular Surgery, Acıbadem Maslak Hospital, Istanbul, Turkey \\ ${ }^{4}$ Department of Anesthesiology and Reanimation, Acıbadem University School of Medicine, Istanbul, Turkey
}

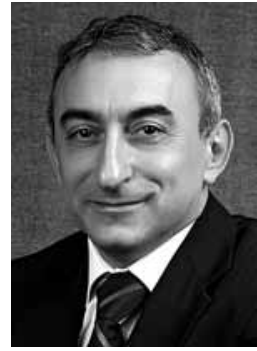

Kardiochirurgia i Torakochirurgia Polska 2014; 11 (4): 385-390

\begin{abstract}
Aim: To investigate the relation between use of bone wax and postoperative sternal dehiscence after cardiac surgery.

Material and methods: Five thousnad three hundred and eighteen consecutive patients who underwent cardiac surgery between 1999 and 2009 were evaluated prospectively. Perioperative use of bone wax, perioperative data and outcome parameters were recorded. Multivariate logistic regression analysis was performed to define independent risk factors for postoperative sternal dehiscence.

Results: Bone wax was used in a total of 1151 (21\%) patients. Postoperative sternal dehiscence was detected in $88(1.6 \%)$ patients. The postoperative sternal dehiscence rate was $1.4 \%$ in patients without bone wax and $2.5 \%$ in patients with bone wax ( $p=0.001)$. The rate of bone wax use was $36.4 \%$ in patients with sternal dehiscence and $21.4 \%$ in patients without sternal dehiscence $(p<0.001)$. Independent risk factors for postoperative sternal dehiscence were defined as: age $>70$ $(\mathrm{OR}=1.9,95 \% \mathrm{Cl}: 1.2-3.1, p=0.005)$, chronic obstructive lung disease $(\mathrm{OR}=2.4,95 \% \mathrm{Cl}: 1.5-3.9, p<0.001)$, use of bone wax $(\mathrm{OR}=1.6,95 \% \mathrm{Cl}: 1.03-2.5, p=0.03)$, nonelective operation $(\mathrm{OR}=2,95 \% \mathrm{Cl}: 1.1-3.4, p=0.009)$, and body mass index $>30$ $(\mathrm{OR}=2.2,95 \% \mathrm{Cl}: 1.4-3.5, p<0.001)$.
\end{abstract}

Conclusions: Our findings suggest that use of bone wax may be associated with increased postoperative sternal dehiscence after cardiac surgery. Thus liberal use of bone wax should be restricted.

Key words: cardiac surgery, sternal dehiscence, bone wax.

\section{Streszczenie}

Cel: Zbadanie związku pomiędzy użyciem wosku kostnego a pooperacyjnym rozejściem mostka po operacjach kardiochirurgicznych.

Materiat i metody: Prospektywnej ocenie poddano kolejnych 5318 pacjentów, którzy przeszli zabiegi kardiochirurgiczne w latach 1999-2009. Odnotowywano okołooperacyjne użycie wosku kostnego, dane okołooperacyjne oraz parametry wyników. Wykonano wielowymiarową analizę regresji logistycznej, aby zdefiniować niezależne czynniki ryzyka dla pooperacyjnego rozejścia mostka.

Wyniki: Wosk kostny zastosowano u tącznie 1151 (21\%) pacjentów. Pooperacyjne rozejście mostka odnotowano u 88 (1,6\%) osób. Wystąpiło ono u 1,4\% pacjentów, u których nie używano wosku kostnego, oraz u 2,5\% pacjentów, u których wosk kostny był stosowany ( $p=0,001)$. Wosk kostny zastosowano u 36,4\% pacjentów, u których wystąpiło rozejście mostka, oraz u 21,4\% pacjentów, u których do niego nie doszło $(p<0,001)$. Niezależne czynniki ryzyka dla pooperacyjnego rozejścia mostka zostały zdefiniowane jako: wiek > 70 lat (OR: 1,9, 95\% Cl: 1,2-3,1, $p=0,005)$, przewlekła obturacyjna choroba płuc $(\mathrm{OR}=2,4,95 \% \mathrm{Cl}: 1,5-3,9, p<0,001)$, stosowanie wosku kostnego $(\mathrm{OR}=1,6,95 \% \mathrm{Cl}: 1,03-2,5, p=0,03)$, operacje nieelektywne (OR: 2, 95\% Cl: 1,1-3,4, $p=0,009$ ), wskaźnik masy ciała $>30$ (OR: 2,2, 95\% Cl: 1,4-3,5, $p<0,001$ ).

Wnioski: Wyniki pracy sugerują, że stosowanie wosku kostnego może być związane ze zwiększoną częstością pooperacyjnego rozchodzenia się mostka po operacjach kardiochirurgicznych. W związku z powyższym uzasadnione może być ograniczenie obfitego stosowania wosku kostnego.

Słowa kluczowe: kardiochirurgia, rozejście mostka, wosk kostny. 


\section{Introduction}

Median sternotomy is currently the main access site for cardiac surgery. The sternal wound is a relatively vulnerable medium in terms of blood supply. The bone consists of a low vascularized tissue, and moreover this vascularization may be damaged especially when internal thoracic arteries are used for coronary bypass grafting. Thus postoperative complications related to sternal healing are not rare [1-3].

The healing sternotomy wound may be complicated with partial or complete dehiscence, sternal wound infection, osteomyelitis or mediastinitis. Sternal dehiscence is increased especially in patients with chronic obstructive pulmonary disease, smoking, obesity, chronic renal failure and diabetes [1].

Bone wax has been used for decades as a physical barrier to maintain hemostasis on the surface edges of bones in cardiac, orthopedic or neurosurgical operations. However, there is no clear recommendation in any guideline, and there still remains controversy regarding the efficiency and the safety of using bone wax. It is a nonabsorbable substance, and there is an increasing amount of evidence that bone wax may produce a foreign body reaction and mechanically inhibit osteoblastic activity, which may eventually lead to increased risk of postoperative sternal dehiscence [1-3].

This study aims to investigate the relation between use of bone wax and postoperative sternal dehiscence after cardiac surgery.

\section{Material and methods}

This prospective observational study used data from consecutive open cardiac surgery procedures performed by one surgical and anesthesia team between 1999 and 2009. A total of 5318 patients were evaluated. Perioperative use of bone wax, perioperative data and outcome parameters were recorded. Multivariate logistic regression analysis was performed to define independent risk factors for postoperative sternal dehiscence.

\section{Decision making for use of bone wax}

The decision to use bone wax was made according to the bleeding status of the sternal edges. There was no standard limit of bleeding; bone wax was used when there was a noticeable amount of bleeding according to the decision of the surgeon.

\section{Anesthesia and perioperative technique}

During CPB, mean arterial pressure and pump flow were kept between $50-80 \mathrm{mmHg}$ and $2.2-2.5 \mathrm{l} / \mathrm{m}^{2}$, respectively. Moderate hypothermia $\left(32^{\circ} \mathrm{C}\right)$ was used during CPB. Myocardial viability was preserved with antegrade cold hyperkalemic crystalloid cardioplegia (Plegisol, Abbott Laboratories, IL, USA) except in patients with a left ventricular ejection fraction less than 0.25 , in whom antegrade + retrograde blood cardioplegia associated with terminal warm blood cardioplegia was used. In the ICU, all hemodynamically stable patients without excessive chest tube drainage and $\mathrm{PaCO}_{2}<48 \mathrm{mmHg}, \mathrm{pH}>7.30$, and $\mathrm{PaO}_{2} / \mathrm{FiO}_{2}>250$ were extubated. We aimed to discharge all patients on the fifth postoperative day. The decision to discharge is based on a satisfactory routine checkup on day 4 consisting of clinical examination, full blood cell count, urea and electrolyte levels, electrocardiogram, and chest roentgenogram.

\section{Data source and definitions}

Our clinical database is used for outcome analysis. It is a prospectively collected record containing relevant patient demographic data, comorbidities, intraoperative variables, and postoperative outcome including postoperative drainage, ventilation time, intensive care unit stay time, hospital stay time, transfusion rate, new onset postoperative renal failure, postoperative stroke, reoperation, arrhythmia, rate of readmission to the intensive care unit, rate of readmission to the hospital, and mortality. The data for use of bone wax were extracted from the institutional operation room database and were combined with the clinical database.

Hospital mortality included all deaths within 30 days of the operation irrespective of where the death occurred and all deaths in the hospital after 30 days among patients who had not been discharged after the operation. Postoperative blood loss was defined as total chest tube drainage. Renal complications included acute renal failure, defined as the requirement of hemodialysis postoperatively. Stroke included postoperative neurological dysfunction that was assessed by a neurologist and documented with radiologic imaging. Cranial imaging was performed when suggested by the neurologist. Delirium was not included in this definition.

The definition of sternal dehiscence included partial or total dehiscence of the sternum at any time postoperatively. Sternal dehiscence was diagnosed with physical examination and/or computed tomographic (CT)/magnetic resonance imaging (MRI) examination. The patients with infection were differentiated from sternal dehiscence according to the microbiologic findings to exclude the sole effect of infection on the development of dehiscence. Pulmonary complications included pneumonia, prolonged ventilator support due to neurologic complications, pulmonary embolic event, bronchial bleeding and pneumothorax.

\section{Statistical analysis}

Data are reported as a percentage or as a mean \pm standard deviation. Univariate comparisons were computed using the $\chi^{2}$ test or Fisher's exact test for categorical variables and $t$ tests for continuous variables. Any factor with a $p$ value of less than 0.1 on univariate analysis was entered into multiple logistic regression. Statistical analysis was performed using SPSS statistical software (SPSS version 11.0, SPSS Inc, Chicago, IL). Variables were considered significant at $p$ values less than 0.05 . 
Tab. I. Preoperative and intraoperative variables

\begin{tabular}{|c|c|c|c|}
\hline Variables & $\begin{array}{c}\text { Postoperative sternal } \\
\text { dehiscence }(-) \\
(n=5230)(98.3 \%)\end{array}$ & $\begin{array}{l}\text { Postoperative sternal } \\
\text { dehiscence }(+) \\
(n=88)(1.7 \%)\end{array}$ & $p$ \\
\hline Mean age (years)* & $59.3 \pm 11.9$ & $59.9 \pm 11.2$ & NS \\
\hline Female gender (\%) & 27.9 & 26.1 & NS \\
\hline NYHA $\geq 3$ (\%) & 30.4 & 36.4 & 0.01 \\
\hline $\operatorname{CCS} \geq 3(\%)$ & 15.2 & 22.7 & NS \\
\hline Preoperative congestive heart failure (\%) & 3.7 & 4.5 & NS \\
\hline Smoking (\%) (current and previous) & 62.6 & 70.4 & NS \\
\hline Hypertension (\%) & 48 & 54.5 & NS \\
\hline Preoperative use of aspirin (\%) & 52.5 & 45.5 & NS \\
\hline Preoperative use of clopidogrel (\%) & 3.9 & 3.4 & NS \\
\hline Diabetes mellitus (\%) & 22.4 & 25 & NS \\
\hline Cardiopulmonary bypass time $>60 \mathrm{~min}(\%)$ & 49 & 56.5 & NS \\
\hline Cardiopulmonary bypass time $>100 \mathrm{~min}(\%)$ & 8.4 & 11.8 & NS \\
\hline
\end{tabular}

NYHA - New York Heart Association, CCS - Canadian Cardiovascular Society Score

Tab. II. Risk factors for sternal dehiscence after cardiac surgery (univariate analysis)

\begin{tabular}{|c|c|c|c|}
\hline Factors & $\begin{array}{c}\text { Postoperative sternal } \\
\text { dehiscence }(-) \\
(n=5230)(98.3 \%)\end{array}$ & $\begin{array}{l}\text { Postoperative sternal } \\
\text { dehiscence }(+) \\
(n=88)(1.7 \%)\end{array}$ & $p$ \\
\hline Use of bone wax (\%) & 21.4 & 36.4 & 0.001 \\
\hline Age $>70$ years $(\%)$ & 17.9 & 34.1 & $<0.001$ \\
\hline Chronic obstructive lung disease (\%) & 14.3 & 33 & $<0.001$ \\
\hline Preoperative use of angiotensin-converting-enzyme inhibitor (\%) & 26.9 & 38.6 & 0.02 \\
\hline Postoperative early reoperation for bleeding or tamponade & 2.5 & 9.1 & 0.001 \\
\hline Perioperative blood transfusion (\%) & 31 & 50 & $<0.001$ \\
\hline Nonelective operation (\%) & 11 & 21.6 & 0.003 \\
\hline Body mass index > 30 (\%) & 26.8 & 44.3 & $<0.001$ \\
\hline
\end{tabular}

\section{Results}

Demographic and perioperative variables are shown in Table I. Bone wax was used in a total of 1151 (21\%) patients. Postoperative sternal dehiscence was detected in 88 (1.6\%) patients. The postoperative sternal dehiscence rate was $1.4 \%$ in patients without bone wax and $2.5 \%$ in patients with bone wax $(p=0.001)$. The rate of bone wax use was $36.4 \%$ in patients with sternal dehiscence and $21.4 \%$ in patients without sternal dehiscence $(p<0.001)$.

Univariate risk analysis revealed the risk factors for developing postoperative sternal dehiscence as: use of bone wax $(p=0.001)$, age $>70$ years $(p<0.001)$, chronic obstructive lung disease $(p<0.001)$, preoperative use of angiotensin-converting enzyme inhibitors (ACEI) $(p=0.02)$, postoperative early reoperation for bleeding or tamponade $(p=0.001)$, perioperative blood transfusion $(p<0.001)$, nonelective operation $(p=0.003)$, and body mass index $>30(p<0.001)$ (Table II).

Independent risk factors for postoperative sternal dehiscence were defined as: age $>70(\mathrm{OR}=1.9,95 \% \mathrm{Cl}$ :

Tab. III. Risk factors for sternal dehiscence after cardiac surgery (multivariate analysis)

\begin{tabular}{lccc} 
Factors & OR & $95 \% \mathrm{Cl}$ & $p$ \\
Age $>70(\%)$ & 1.9 & $1.2-3.1$ & 0.005 \\
\hline $\begin{array}{l}\text { Chronic obstructive lung } \\
\text { disease (\%) }\end{array}$ & 2.4 & $1.5-3.9$ & $<0.001$ \\
\hline Use of bone wax & 1.6 & $1.03-2.5$ & 0.03 \\
\hline Nonelective operation & 2 & $1.1-3.4$ & 0.009 \\
\hline Body mass index $>30$ & 2.2 & $1.4-3.5$ & $<0.001$ \\
\hline
\end{tabular}


Tab. IV. The effect of sternal dehiscence on outcome parameters

\begin{tabular}{lccc} 
Parameters & $\begin{array}{c}\text { Postoperative sternal } \\
\text { dehiscence }(-) \\
(n=5230)(98.3 \%)\end{array}$ & $\begin{array}{c}\text { Postoperative sternal } \\
\text { dehiscence }(+) \\
(n=88)(1.7 \%)\end{array}$ & 20.2 \\
\hline Intensive care unit readmission (\%) & 2.8 & 12.5 & $<0.001$ \\
\hline Need for reintubation (\%) & 1.8 & 56.6 & $<0.001$ \\
\hline Hospital readmission (\%) & 3.4 & 36.4 & $<0.001$ \\
\hline Postoperative sternal infection (\%) & 0.8 & 4.5 & $<0.001$ \\
\hline Mortality (\%) & 1.6 & 2 & 0.001 \\
\hline Permanent neurological stroke & 0.3 & 2.6 & $<0.001$ \\
\hline Transient neurological attack & 0.8 & 22.7 & $<0.001$ \\
\hline New onset atrial fibrillation (\%) & 11.8 & 0.007 \\
\hline
\end{tabular}

1.2-3.1, $p=0.005)$, chronic obstructive lung disease (OR = $2.4,95 \% \mathrm{Cl}: 1.5-3.9, p<0.001)$, use of bone wax (OR $=1.6$, $95 \% \mathrm{Cl}: 1.03-2.5, p=0.03)$, nonelective operation (OR $=2$, $95 \% \mathrm{Cl}: 1.1-3.4, p=0.009)$, and body mass index $>30$ (OR = 2.2, $95 \%$ Cl: 1.4-3.5, $p<0.001$ ) (Table III). Postoperative adverse outcome parameters including rate of ICU readmission, need for reintubation, rate of hospital readmission, rate of postoperative sternal infection, mortality, permanent neurological stroke rate, transient neurological attack rate, and rate of new onset atrial fibrillation were observed at a higher rate in patients with sternal dehiscence (Table IV). The mean EuroSCORE value of patients with bone wax was higher when compared to patients without bone wax (3.9 \pm 2.7 vs. $4.9 \pm 3.1 ; p<0.001)$.
Demographic and perioperative variables in patients with bone wax and without bone wax and the effect of bone wax use on outcome parameters are shown in Table V and VI.

\section{Discussion}

The main finding of this study is the demonstration of a relation between use of bone wax and postoperative sternal dehiscence. Additional risk factors for sternal dehiscence were defined as age $>70$, chronic obstructive lung disease, nonelective operation and body mass index $>30$.

Secondly, the effect of postoperative sternal dehiscence on outcome parameters was identified. Rate of ICU readmission, need for reintubation, hospital readmission, postoperative sternal infection, mortality, permanent neu-

Tab. V. Demographic and perioperative variables in patients with bone wax and without bone wax

\begin{tabular}{|c|c|c|c|}
\hline Variables & $\begin{array}{c}\text { Group } 1 \\
\text { Bone wax (-) } \\
(n=4167)(79 \%)\end{array}$ & $\begin{array}{c}\text { Group } 2 \\
\text { Bone wax }(+) \\
(n=1151)(21 \%)\end{array}$ & $p$ \\
\hline Mean age (years) & $59.3 \pm 11.9$ & $59.9 \pm 11.2$ & NS \\
\hline EuroSCORE (\%) & $3.9 \pm 2.7$ & $4.9 \pm 3.1$ & $<0.001$ \\
\hline Female gender & 28.4 & 25.9 & NS \\
\hline NYHA $\geq 3(\%)$ & 13.7 & 21.2 & $<0.001$ \\
\hline $\operatorname{CCS} \geq 3(\%)$ & 30 & 32.2 & 0.03 \\
\hline Preoperative congestive heart failure (\%) & 3 & 6.5 & $<0.001$ \\
\hline Hypertension (\%) & 48 & 48.7 & NS \\
\hline Chronic lung disease (\%) & 13.8 & 17.5 & 0.001 \\
\hline Preoperative use of aspirin (\%) & 53 & 50.1 & NS \\
\hline Preoperative use of clopidogrel (\%) & 3.6 & 5.1 & 0.02 \\
\hline Preoperative use of heparin (\%) & 3.6 & 7.1 & $<0.001$ \\
\hline Ejection fraction < $50(\%)$ & 32.9 & 32.4 & NS \\
\hline Nonelective operation (\%) & 9.8 & 16.2 & $<0.001$ \\
\hline Redo operation (\%) & 5.6 & 8.6 & $<0.001$ \\
\hline Preoperative atrial fibrillation (\%) & 2.1 & 1.1 & NS \\
\hline Diabetes mellitus (\%) & 22.8 & 20.8 & NS \\
\hline Body mass index > $30(\%)$ & 25.5 & 32.7 & $<0.001$ \\
\hline Cardiopulmonary bypass time (min) & $62 \pm 25$ & $70 \pm 30$ & $<0.001$ \\
\hline Cardiac arrest time (min) & $38 \pm 19$ & $45 \pm 24$ & $<0.001$ \\
\hline
\end{tabular}

NYHA - New York Heart Association Score, CCS - Canadian Cardiovascular Society Score 
Tab. VI. The effect of use of bone wax on outcome parameters

\begin{tabular}{|c|c|c|c|}
\hline Parameters & $\begin{array}{c}\text { Group } 1 \\
\text { Bone wax }(-) \\
(n=4167)(79 \%)\end{array}$ & $\begin{array}{c}\text { Group } 2 \\
\text { Bone wax }(+) \\
(n=1151)(21 \%)\end{array}$ & $p$ \\
\hline Mean drainage $(\mathrm{ml})$ & $600 \pm 359$ & $652 \pm 457$ & $<0.001$ \\
\hline Patients with drainage > $1000 \mathrm{ml}(\%)$ & 10.3 & 14.1 & $<0.001$ \\
\hline Nontransfused patients (\%) & 69.6 & 62.8 & $<0.001$ \\
\hline Ventilation time (h) & $5.7 \pm 11.2$ & $9.2 \pm 33.9$ & $<0.001$ \\
\hline Ventilation time > 8 hours (\%) & 13.9 & 26.2 & $<0.001$ \\
\hline Intensive care unit stay time (h) & $23 \pm 18.8$ & $33.7 \pm 76.7$ & $<0.001$ \\
\hline Intensive care unit stay time $>24$ hours & 7.3 & 15.5 & $<0.001$ \\
\hline Duration of hospital stay $(\mathrm{d})$ & $5.5 \pm 3.7$ & $6.9 \pm 6.7$ & $<0.001$ \\
\hline Intensive care unit readmission (\%) & 2.7 & 4.7 & 0.001 \\
\hline Need for reintubation (\%) & 1.7 & 2.7 & 0.04 \\
\hline Hospital readmission (\%) & 3.6 & 6.9 & $<0.001$ \\
\hline Postoperative sternal dehiscence (\%) & 1.3 & 2.8 & 0.001 \\
\hline Postoperative sternal infection (\%) & 1.3 & 1.7 & NS \\
\hline Mortality & 1.4 & 2.5 & 0.001 \\
\hline Permanent neurological stroke & 0.2 & 0.8 & 0.002 \\
\hline Transient neurological attack & 0.7 & 1.3 & 0.002 \\
\hline New onset atrial fibrillation (\%) & 11.4 & 14.1 & $<0.001$ \\
\hline Pulmonary complication (\%) ${ }^{\star}$ & 0.6 & 0.9 & NS \\
\hline
\end{tabular}

*Pulmonary complications included: pneumonia, prolonged ventilator support due to neurologic complications, pulmonary embolic event, bronchial bleeding and pneumothorax.

rological stroke, transient neurological attack and new onset atrial fibrillation were quite higher in the patients with sternal dehiscence.

Remembering the wide and unrestricted use of bone wax in cardiac surgery, any cardiac surgeon, especially the younger ones during their initial training periods, naturally may arrive at the conclusion that this is a safe and effective application with no need for any further consideration. In fact, this kind of prejudgment is not uncommon in the basic concepts of traditional cardiac surgery implementations such as cardiopulmonary bypass and blood transfusion. However, a short review of scientific evidence can make anyone see that it is not the case.

Literature data lack information regarding the efficiency and safety of using bone wax in cardiac surgery. Not only the adverse effects but also the potential benefits of bone wax require consideration [3-18].

Bone wax was first introduced in medicine in 1886 [4, 5]. It is supplied in sterile sticks and is used as a topical hemostatic material composed of a softening agent such as Vaseline and beeswax, which is a natural wax produced in the beehive of honey bees [6]. When it is applied on the surface of bones, it remains indefinitely and may lead to various adverse effects. The 5 major characteristics of bone wax which may be associated with its nature and reported adverse effects and related scientific considerations are stated below: 1. The primary reason for using bone wax is to maintain hemostasis. In fact, it has no biological or chemical hemostatic effect. The hemostatic effect of bone wax is mainly related to its physical blocking of the holes in the bone and stopping the blood flow from damaged vessels into the bone. However, the literature data do not support a reduction of blood or blood product consumption as a result of a presumably decreased perioperative blood loss when using bone wax [4]. This study also was unable to demonstrate a benefit in terms of drainage and use of blood products with bone wax. Despite mean drainage, the proportion of patients with drainage $>1000 \mathrm{ml}$ and the proportion of transfused patients were higher in patients with bone wax.

2. Bone wax is known to interfere with bone healing and osteogenesis. It inhibits osteoblastic activity, prevent bone healing and may lead to creation of a pseudoarthrosis [1, 2, 5-9]. This may be less important in healing of partial or immobile bone wounds. However, a sternal wound is always under the exertion of dynamics of a mobile thorax. Thus the osteogenesis and the wound healing are more important than any other site of bone wax implementation. It is reported that persistent sternal nonunion and chronic inflammatory reactions with the presence of residual bone wax exist up to 10 years after the operation [2-4]. Postoperative sternal dehiscence was detected more than 2 times in patients with bone wax in this study. Moreover, bone wax was determined as an independent risk factor for postoperative sternal dehiscence. This may lead us to consider that it is not appropriate to use bone wax in areas where bone fusion is extremely important such as sternotomy incisions.

3. When bone wax is applied on the surface of the bone, it is not absorbed or metabolized. This may induce a for- 
eign body reaction characterized by giant cells, plasma cells, fibrous tissue, and a lack of bone formation, which may eventually trigger an allergic reaction or granuloma formation [5-9]. Bone wax granulomas have been reported in mastoid tissue, the sternotomy site, the lumbar disc surgical site, the cerebellopontine angle, the subarachnoid space near the medulla oblongata, the femoral neck osteoplasty site, orbits, cranial defects, after tibial tubercle elevation surgery and after foot surgery [11]. In an anatomico-pathological study of $18 \mathrm{ca}$ davers, it was reported that bone wax induces chronic inflammation and granuloma formation in the sternum postoperatively $[12,13]$. Interestingly, the computed tomographic (CT) examination which is usually decided as the first diagnostic choice for the management of a patient with sternal dehiscence was unable to detect bone wax-related granuloma [12, 13]. Thus magnetic resonance imaging $(\mathrm{MRI})$ is recommended for evaluation of a complicated sternal wound. The diagnosis of sternal dehiscence or granuloma formation was not the subject of this study, but personal observations of the authors indicate that granuloma formation is a rare but serious complication which may advance the decision for reoperation, and routine radiologic imaging (MRI or (T) is usually not necessary but MRI should be the choice.

4. Bone wax acting as a foreign material has been shown to reduce bacterial clearance in bone tissue and to increase the risk of infection. Several publications have established that microorganisms can adhere to foreign material, leading to a low virulence infection with a slow onset [14, 15]. Usually, the host immune mechanisms are able to eradicate such infections, but in some morbid patients with diabetes mellitus or renal failure this may result in a persistent infection. Bone wax can be regarded as a foreign body in this respect, representing a possible site for low virulence pathogens which may trigger sternal wound infection, sternocutaneous fistula or mediastinitis $[14,15]$. For the management and diagnosis of these complications, MRI is recommended [16]. The postoperative sternal infection rate was higher in patients with bone wax in this study; however, statistical difference was not observed. This may imply that we may avoid using bone wax in any site, especially in immunocompromised patients.

5. Bone wax was shown to be related to pulmonary embolic events in an experimental study in which radioactively labeled bone wax applied at the sternal wound was found in significant quantities in the lung. This shows that bone wax may embolize and may give rise to secondary pulmonary complications [9]. In this study, the rate of pulmonary complications was higher when bone wax was used, but the difference was not statistically significant. Regarding these considerations, use of bone wax in any site should be restricted, especially in patients with preoperative pulmonary dysfunction.

\section{Conclusions}

Our findings suggest that use of bone wax may be associated with increased postoperative sternal dehiscence, which leads to an impaired outcome after cardiac surgery. Thus liberal use of bone wax should be restricted. Alternatively, products which are absorbable, less prone to tissue reaction, do not interfere with bone healing and have platelet-stimulating effects, such as microfibrillar collagen, oxidized regenerated cellulose, and gelatin foam, might be an appropriate choice.

This study is not designed to compare two groups of patients according to the use of bone wax. The patients with bone wax are more complicated, with a higher mean EUROSCORE. Thus any comparison of outcomes between the two groups may not reflect the exact situation.

\section{Disclosure}

Authors report report no conflict of interest.

\section{References}

1. Losanoff JE, Richman RW, Jones JW. Disruption and infection of median sternotomy: a comprehensive review. Eur J Cardiothorac Surg 2002; 21: 831-839.

2. Ragusa R, Faggian G, Rungatscher A, Cugola D, Marcon A, Mazzucco A. Use of gelatin powder added to rifamycin versus bone wax in sternal wound hemostasis after cardiac surgery. Interact Cardiovasc Thorac Surg 2007; 6: 52-55.

3. Bhatti F, Dunning J. Does liberal use of bone wax increase the risk of mediastinitis? Interact Cardiovasc Thorac Surg 2003; 2: 410-412.

4. Prziborowski J, Hartrumpf M, Stock UA, Kuehnel RU, Albes JM. Is bonewax safe and does it help? Ann Thorac Surg 2008; 85: 1002-1006.

5. Tan TC, Black PM. Sir Victor Horsley (1857-1916): pioneer of neurological surgery. Neurosurgery 2002; 50: 607-611.

6. Schonauer C, Tessitore E, Barbagallo G, Albanese V, Moraci A. The use of local agents: bone wax, gelatin, collagen, oxidized cellulose. Eur Spine J 2004; 13 Suppl 1: S89-96.

7. Ibarrola JL, Bjorenson JE, Austin BP, Gerstein H. Osseous reactions to three hemostatic agents. J Endod 1985; 11: 75-83.

8. Alberius $P$, Klinge $B$, Sjögren S. Effects of bone wax on rabbit cranial bone lesions. J Craniomaxillofac Surg 1987; 15: 63-67.

9. Katz SE, Rootman J. Adverse effects of bone wax in surgery of the orbit. Ophthal Plast Reconstr Surg 1996; 12: 121-126.

10. Robicsek F, Masters TN, Littman L, Born GVR. The embolization of bone wax from sternotomy incisions. Ann Thorac Surg 1981; 31: 357-359.

11. Qayum A, Koka AH. Foreign body reaction to bone wax an unusual cause of persistent serous discharge from iliac crest graft donor site and the possible means to avoid such complication - a case report. Cases J 2009; 2: 9097.

12. Ozdemir N, Gelal MF, Minoglu M, Celik L. Reactive changes of disc space and foreign body granuloma due to bone wax in lumbar spine. Neurol India 2009; 57: 493-496.

13. Sudmann B, Bang G, Sudmann E. Histologically verified bone wax (beeswax) granuloma after median sternotomy in 17 of 18 autopsy cases. Pathology 2006; 38: 138-141.

14. Darouiche RO. Treatment of infections associated with surgical implants. N Engl J Med 2004; 350: 1422-1429

15. Steingrímsson S, Gustafsson R, Gudbjartsson T, Mokhtari A, Ingemansson R, Sjögren J. Sternocutaneous fistulas after cardiac surgery: incidence and late outcome during a ten-year follow-up. Ann Thorac Surg 2009; 88: 1910-1915.

16. Silber JS, Anderson DG, Vaccaro AR, Anderson PA, McCormick P. NASS Management of postprocedural discitis. Spine J 2002; 2: 279-287

17. Wellisz T, Armstrong JK, Cambridge J, An YH, Wen X, Kang Q, Hill CM, Fisher TC. The effects of a soluble polymer and bone wax on sternal healing in an animal model. Ann Thorac Surg 2008; 85: 1776-1780.

18. Milano CA, Kesler K, Archibald N, Sexton D. Mediastinitis after coronary artery bypass surgery: risk factors and long-term survival. Circulation 1995; 92: 2245-2251. 